\title{
FINANCIAL PERFORMANCE FOR LOCAL COMPANIES : POLITICAL EVENT STUDY IN SURABAYA
}

\author{
Dr. Wiliam Santoso, S.E., M.Ak. \\ Universitas Pelita Harapan, Kampus Surabaya \\ william.santoso@uph.edu
}

\begin{abstract}
The purpose of this research is to determine the differences of financial performance and market performance before, as at, and after direct election for local government executive. This research picks 28 Surabaya based listed companies as samples based on purposive sampling method with several criteria during local government election. Method of hypothesis testing uses multivariate analysis of variance (manova) and Kruskal Wallis test with three groups of periods, which are before, as at, and after the direct election for local government executive. The results show that there is no significant financial performance of local based company in Surabaya caused by direct local government election measured by current ratio, working capital turnover ratio, debt to asset and return to asset ratio. The market performance test shows that the there is significant difference of company's abnormal return before, as at, and after the direct election for local government executive. Furthermore, the abnormal return after the direct election for local government executive was significant higher than as at the election year.
\end{abstract}

Keyword: Financial Performance, Market Performance, Financial Ratio, Indonesia Stock Exchange

\section{INTRODUCTION}

"Politics is a continuation of economics by other means" is a popular quote by Ruppert (2009) on Collapse movie. This quote shows that politics have particular connection with economic. As a part of economic activities, capital market may be influenced by political issue. According to Freeman et. al. (2000), politics influenced the performance of financial markets. Politics is considered as important issue for investors even for companies. One of the most awaited political events is leader election, especially presidential election. In Indonesia case, after 2005, people also elect the local district head by themselves, such as governor, mayor, and regent. Thus, there will be several direct election process, besides the presidential election.

According to Berman and Haque (2015), the modern economy of Indonesia, especially in Java are driven by two cities, Jakarta (colonial Batavia) and Surabaya. Surabaya is the second largest city in Indonesia. Applying dockyards and industry, Surabaya grew into one of the great port cities in Asia ranking along with Calcutta, Rangoon, Singapore, Bangkok, Hong Kong, and Shanghai. Thus, the leader of Surabaya city would be a very strategic and prestigious position to be.

Since regulation about direct election for local government executive has been implemented, Surabaya has performed three times mayor elections. Election on 2010 is won by Tri Rismaharini. This is an interesting case, because it is the first time a candidate can be nominated through independent way, instead through political parties. Thus, the competition was very tight. There were five pair candidates competed on the election and the candidate who won the election will be the new mayor for Surabaya since the incumbent mayor participated as vice mayor for the 
mayor candidate, Tri Rismaharini. The tight of competition was still remained until the end of election since one of the candidates contested the election result on constitutional court. Through several assemblies, the constitutional court announced the election of Surabaya is won by Tri Rismaharini with 40,9\% vote, greater than the close competitor, Arif Afandi with $36,4 \%$ vote.

This election was the democracy portrait in Indonesia. The elected mayor was expected to bring Surabaya better on several aspects: economy, education, healthy, city cleanliness, and others. The higher economy growth should benefit for the local companies which are based on Surabaya. There were several stock exchange-listed companies in Surabaya. Their performance can be indicator to measure the prosperity improvement on Surabaya as the side effect of post election period.

If the local leader really can influence the local economic circumstances, the direct election in Surabaya should influence performance of Surabaya and surroundings based companies, both in financial and market performance. Thus, there should be significant difference of local based company's financial and market performance before and after the election. This research focuses to discuss on this issue.

\section{LITERATURE REVIEW}

\subsection{PREVIOUS STUDY}

Previous studies exhibit various findings about influence of politic events to economic context. According to Allvine and O'Neill (1980), the gains to be made in short run from exploiting the four year cycle will generally be small, while the risks is high because of high short run volatility. The result strongly favors stock prices rising relative to trend over the two years prior to presidential election. The investors are advised to not ignore the phase of election cycle in timing the market. According to Herbst and Slinkman (1984), the 48-month stock market cycle is closely associated with US presidential elections, a political economic cycle. Although the evidence supports the existence of 24 month cycle, its peak is not close to election date. Stock market when elections in prospect is more bullish than elections in retrospect.

According to Clara and Valkanov (2003), the presidential cycle variables capture information about returns which is not correlated with business cycle variables. The difference in returns across presidential parties consist larger difference in unexpected returns rather than in expected returns. Given this finding, the suggested mechanism through which political variables impact to stock returns is through economic policies. The differences in policies between the parties were unexpected and make investors surprise throughout the presidential mandates.

According to Leblang and Mukherjee (2005), stock markets in the United States and Britain have been quite sensitive to elections and partisan politics. The sensitivity of financial markets indicates that the incumbent party can adopt monetary and fiscal policies that affect both real economic outcomes and price movements in stock market. It is also plausible for incumbents for attempting influence stock market to enhance their electoral prospects. The interesting finding is that market returns increase under right wing administrations. This indicates a positive welfare effect. It is also suggested that agents in United States and Britain stock markets are genuinely concerned that the parties will remain commit to maximize redistribution and welfare programs after elections using several policies. They may lower the stock prices.

According to Beaulieu et. al. (2006), the short run effect of referendum results on stock return is positive and statistically significant for all four portfolios. The results clearly reveal that political uncertainty can affect short run returns when the uncertainty can not be anticipated by financial markets. The effect of uncertainty in referendum is larger for firms most exposed to political risk than for firms less exposed to political risk. This uncertainty is less important for multinational companies than for domestic companies.

According to Huber and Kirchler (2013), companies that had supported the elected 
president during his campaign and give contributions on him enjoyed positive and significant abnormal returns. The percentage of contributions given to the winner in a presidential election and the total contribution significantly increased a company's abnormal stock return in the two years after an election on the period $1992-2006$.

\subsection{POLITICS AND ECONOMIC RELATION}

According to Clark (1998), although the market is usually viewed as an economic institution, it has a strategic role in achieving the political goal of justice. The market's role as political institution can be understood in three dimensions: freedom, equity, and order. The market provides freedoms because individuals have the right to make their own choices related employment, consumption pattern, and social relationship. For the equity reason, the market distributes rewards according to each person's ability to provide valuable resources through the forces of supply and demand mechanism. The market erodes traditional human relations based on arbitrary privilege and hierarchy. Freedom of choice and sense of autonomy contribute to personal well being usually implies an orderly society. The market also fosters order by increasing specialization of labor, so that formerly separate groups become mutually dependent.

According to Dixit (1996), perfect markets and perfect governments do an equally good job of achieving economic efficiency. The role of perfect government was interpreted as correcting market failures, such as using subsidies to replace missing markets or correct externalities, providing public goods, and achieving desirable resources distribution. Three way objectives classifications and administration of fiscal policy and budget: allocation of public goods or services, wealth distribution with taxes and transfers, and stabilization on noninflationary level of aggregate demand and employment in economy.

According to Dahl and Lindblom (2000), the number of alternative politico - economics techniques is very large. For example, the alternative form of business can consist of proprietorship, partnership, and corporation. Corporations may be relatively simple structure of family business or could be complex bureaucracies with owner or without owner control. Each corporation is operating under minimum regulations by government regarding its nature of business. Politics involved inside the company by determining policy and also influenced company from external by regulation made by government.

\subsection{FINANCIAL PERFORMANCE}

Financial performance is defined using financial ratio. According to Titman et. al. (2011), financial ratios provide a method for standardizing the financial information in the income statement and financial position. The company's health condition can be measured by comparing the firm's current financial ratio to its past ratios to see if there is moving up or moving down performance or comparing the firm's ratios to its competitors. If the differences in the ratios are significant, more in depth analysis should be done, but at least financial ratios essentially provide the analyst with clues. There are several financial ratios. This research uses liquidity ratio, activity ratio, solvency ratio, and profitability ratio. The financial ratios used in this research are presented on table 1 below.

Table 1. Financial Ratio Formula

\begin{tabular}{|c|c|}
\hline Financial Ratio & Formula \\
\hline Liquidity Ratio & Current ratio $=\frac{\text { current assets }}{\text { current liabilities }}$ \\
\hline Activity Ratio & Working Capital Turnover Ratio $=\frac{\text { total revenue }}{\text { current assets }- \text { current liabilities }}$ \\
\hline Solvency Ratio & Debt to Asset Ratio $=\frac{\text { total debts }}{\text { total assets }}$ \\
\hline
\end{tabular}




\begin{tabular}{|l|l|}
\hline Profitability Ratio & Return to Asset $=\frac{\text { net income }}{\text { total assets }}$ \\
\hline
\end{tabular}

Titman et. al. (2011)

\subsection{MARKET PERFORMANCE}

Market performance is defined as abnormal return. According to Morck (2000), abnormal return is calculated as the difference between the actual stock return and the market return as below formula.

While:

$$
\mathrm{AR}_{\mathrm{it}}=\mathrm{R}_{\mathrm{it}}-\mathrm{R}_{\mathrm{mt}}
$$

$\mathrm{AR}_{\mathrm{it}} \quad=$ abnormal return of company-i at $\mathrm{t}$-period

$\mathrm{R}_{\mathrm{it}}=$ actual stock return of company-i at t-period

$\mathrm{R}_{\mathrm{mt}}=$ market return of company-i at $\mathrm{t}$-period

\subsection{THEORITICAL FRAMEWORK}

Figure 1. Theoritical Framework

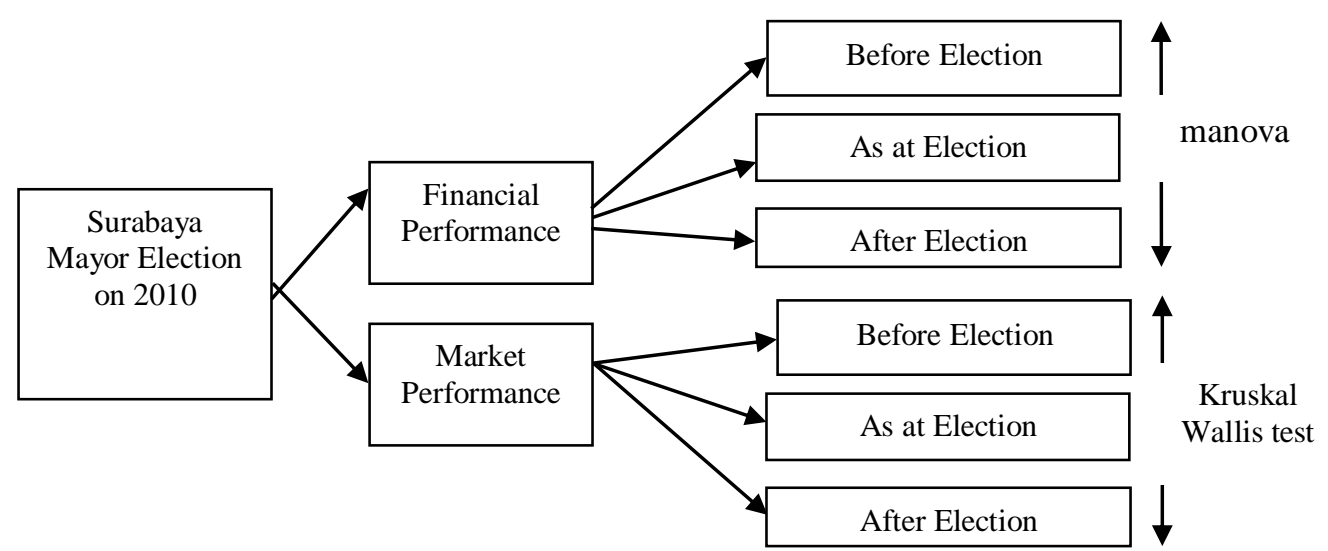

\subsection{RESEARCH HYPOTHESES}

Based from the literature reviews, two hypotheses were formulated on this research.

$\mathrm{H}_{1} \quad$ : There is significant difference of local based company's current ratio, working capital turnover ratio, debt to asset and return to asset ratio before, as at, and after direct election for local government executive.

$\mathrm{H}_{2} \quad$ : There is significant difference of local based company's abnormal return before, as at, and after direct election for local government executive.

\section{RESEARCH METHODS}

\subsection{RESEARCH SAMPLES}

This research used financial report and stock trading report of Indonesia Stock Exchange listed companies which is headquartered or mainly operated in Surabaya as samples using purposive sampling method. This research set the following criteria for samples:

- Companies which have published financial report before, as at, and after direct election for local government executive. 
- Companies which have had complete stock trade report before, as at, and after direct election for local government executive.

- Excludable for companies come from banking industry, because banking industry has different financial ratios to measure their performance.

Based on those criteria, 28 public companies are picked as samples.

\subsection{DATA SOURCES}

This research use secondary data which is acquired from Indonesia Capital Market Directory, company's financial report, company's annual report, and yahoo finance.

\subsection{ANALYSIS METHOD}

This research uses statistic analysis method. $\mathrm{H}_{1}$ argue that there is significant difference of local based company's current ratio, working capital turnover ratio, debt to asset and return to asset ratio before, as at, and after direct election for local government executive. The difference of these three periods of financial ratios is tested using multivariate analysis of variance (manova). Manova is considered as an appropriate method because the research compares four groups of financial ratio variable and three groups of period variable. Manova needs several precondition tests, such as: normality test, separate variance homogeneity test, and simultaneously variance homogeneity test in order to make sure that the model meet several manova assumptions.

$\mathrm{H}_{2}$ is tested using Kruskal Wallis test. Kruskal Wallis test is nonparametric statistic test, so it still can be applied to test $\mathrm{H}_{2}$ even though $\mathrm{H}_{2}$ fails to meet variance homogeneity test or if there is any problem with data normality. The research's analysis methods are listed on table 2.

Table 2. Analysis Method

\begin{tabular}{|c|c|c|c|c|c|}
\hline Hypotheses & Method & $\begin{array}{c}\text { Precondition } \\
\text { test }\end{array}$ & Type of test & $\begin{array}{l}\text { Precondition test } \\
\text { decision making }\end{array}$ & $\begin{array}{l}\text { Hypotheses test } \\
\text { decision making }\end{array}$ \\
\hline \multirow[t]{3}{*}{$\mathrm{H}_{1}$} & \multirow[t]{3}{*}{ MANOVA } & Normality & $\begin{array}{l}\text { Kolmogorov } \\
\text { Smirnov }\end{array}$ & $\begin{array}{l}\text { - } \text { sig. }>0,05 \text {; normal } \\
\text { distribution. } \\
\text { - sig. < } 0,05 \text {; } \\
\text { abnormal } \\
\text { distribution. }\end{array}$ & \multirow[t]{3}{*}{$\begin{array}{l}\text { - } \text { sig. }<0,05 \text { then } \mathrm{H}_{0} \\
\text { is rejected. } \\
\text { - } \text { sig }>0,05 \text { then } \mathrm{H}_{0} \text { is } \\
\text { accepted. }\end{array}$} \\
\hline & & $\begin{array}{l}\text { Separate } \\
\text { variance } \\
\text { homogeneity } \\
\text { test }\end{array}$ & Levene Test & $\begin{array}{l}\text { - } \text { sig. > 0,05; equal } \\
\text { variance. } \\
\text { - } \text { sig. < } 0,05 \text {; } \\
\text { unequal variance. }\end{array}$ & \\
\hline & & $\begin{array}{l}\text { Simultaneously } \\
\text { variance } \\
\text { homogeneity } \\
\text { test }\end{array}$ & $\begin{array}{l}\text { Box's } \quad \text { M } \\
\text { Test }\end{array}$ & $\begin{array}{l}\text { - } \text { sig. >0,05; equal } \\
\text { covariance matrix } \\
\text { - sig. < } 0,05 \text {; } \\
\text { unequal covariance } \\
\text { matrix }\end{array}$ & \\
\hline
\end{tabular}

Source: Hair et. al. (2006)

\section{RESULTS AND DISCUSSION \\ 4.1. PRECONDITION TEST}

Precondition test results for manova analysis model are provided below.

Table 3. Precondition Test Results

\begin{tabular}{|l|l|l|l|l|}
\hline Hypotheses & Method & Type of Test & Result & Explanation \\
\hline
\end{tabular}




\begin{tabular}{|l|l|l|l|l|}
\hline $\mathrm{H}_{1}$ & MANOVA & Kolmogorov & & \\
& & & \\
& & Smirnov & 0.000 & Abnormal distribution \\
& & CR & 0.000 & Abnormal distribution \\
& WCTO & 0.000 & Abnormal distribution \\
& DAR & 0.000 & Abnormal distribution \\
\hline \multirow{5}{*}{} & ROA & & \\
\cline { 3 - 5 } & Levene Test & 0.227 & Homogeneous variance \\
& CR & 0.056 & Homogeneous variance \\
& WCTO & 0.869 & Homogeneous variance \\
& DAR & 0.711 & Homogeneous variance \\
\hline & ROA & 0.000 & Heterogeneous variance \\
\hline
\end{tabular}

Source: Data processing.

Precondition test results of manova analysis model show that the model has equal variance (homogeneous variance) with unequal covariance (heterogeneous variance) matrix. According to Gozali (2011), manova analysis model is still robust to be tested, although precondition test results are failed to fulfill normality and variance homogeneity assumptions. Since second hypothesis is tested using Kruskal Wallis test (non parametric test), it is no need to perform precondition test for second hypothesis.

\subsection{MANOVA ANALYSIS}

$\mathrm{H}_{1}$ is tested using multivariate analysis of variance. The results are provided on table 4 .

Table 4. MANOVA Analysis Results

\begin{tabular}{|l|l|l|l|l|}
\hline \multicolumn{1}{|c|}{ Effect } & \multicolumn{1}{c|}{ Value } & F & Sig. & \multicolumn{1}{c|}{ Explanation } \\
\hline Pillai's Trace & 0.047 & 0.474 & 0.873 & $\mathrm{H}_{0}$ is accepted \\
\hline Wilks'Lambda & 0.954 & 0.469 & 0.876 & $\mathrm{H}_{0}$ is accepted \\
\hline Hotelling's Trace & 0.048 & 0.464 & 0.880 & $\mathrm{H}_{0}$ is accepted \\
\hline Roy's Largest Root & 0.036 & 0.711 & 0.587 & $\mathrm{H}_{0}$ is accepted \\
\hline Test of Between Subjects & & & & \\
CR & - & 0.512 & 0.601 & $\mathrm{H}_{0}$ is accepted \\
WCTO & - & 0.965 & 0.385 & $\mathrm{H}_{0}$ is accepted \\
DAR & - & 0.018 & 0.982 & $\mathrm{H}_{0}$ is accepted \\
ROA & - & 0.232 & 0.793 & $\mathrm{H}_{0}$ is accepted \\
\hline
\end{tabular}

Source: Data processing.

Multivariate analysis of variance results show that $\mathrm{H}_{0}$ is accepted. It means that there is no significant difference of company's current ratio, working capital turnover ratio, debt to asset and return on asset ratio before, as at, and after the direct election for local government executive. Furthermore, test of between subjects reveal that there is no significant difference for all four financial ratios which is caused by different period of election year. These results reveal that direct election for local government executive did not make any significant difference impact on company's financial performance. 


\subsection{KRUSKAL WALLIS ANALYSIS}

$\mathrm{H}_{2}$ is tested using Kruskal Wallis test. The results are provided on the table 6.

Table 5. Kruskal Wallis Test Results

\begin{tabular}{|l|c|}
\hline & Abnormal Return \\
\hline Chi Square & 12.397 \\
\hline Df & 2 \\
\hline Sig. & 0.002 \\
\hline
\end{tabular}

Source: Data processing.

Kruskal Wallis test show that sig. value is less than significant level $(\alpha=0,05)$, then $\mathrm{H}_{0}$ is rejected and $\mathrm{H}_{2}$ is accepted. It means that there is significant difference of company's abnormal return before, as at, and after the direct election for local government executive. Further post hoc test is needed because Kruskal Wallis test can not reveal which pair specifically is significant different, whether higher or lower. Wilcoxon Signed Rank Test is applied as post hoc test of Kruskal Wallis test. The results are on table 6.

Table 6. Wilcoxon Signed Rank Analysis Results

\begin{tabular}{|c|c|c|c|c|c|c|c|}
\hline $\begin{array}{c}\text { Hypo } \\
\text { theses }\end{array}$ & Pair & Z & Sig. & Explanation & \multicolumn{2}{|c|}{ Rank } & Explanation \\
\hline $\mathrm{H}_{21}$ & Before - As at & -0.068 & 0.946 & $\mathrm{H}_{0}$ is accepted & 11 & 17 & Before $<$ As at \\
\hline $\mathrm{H}_{22}$ & As at - After & -2.915 & 0.004 & $\mathrm{H}_{0}$ is rejected & 7 & 21 & As at $<$ After \\
\hline $\mathrm{H}_{23}$ & Before - After & -1.799 & 0.072 & $\mathrm{H}_{0}$ is accepted & 9 & 19 & Before $<$ After \\
\hline
\end{tabular}

Source: Data processing.

Wilcoxon signed rank test analysis results show that only $\mathrm{H}_{22}$ is accepted and the two others are rejected. They mean that significant difference of abnormal return exist only when comparison period between as at and after the direct election for local government executive. There is no significant difference of abnormal return on other comparison periods.

Since only $\mathrm{H}_{22}$ is accepted, the significant difference of abnormal return only exists on as at and after the direct election for local government executive. The abnormal return as at the direct election for local government executive is significant lower than after or in other word, the abnormal return after the direct election for local government executive is significant higher than as at the election year. Although, wilcoxon signed rank test shows the abnormal return before is lower than as at the direct election for local government executive, the difference is not significant. It also happened on before and after periods, although abnormal return before the direct election for local government executive is lower than after, it is not significant.

\section{ANALYSIS AND DISCUSSION}

\subsection{THE EFFECT OF DIRECT ELECTION FOR LOCAL GOVERNMENT EXECUTIVE TO FINANCIAL PERFORMANCE OF LOCAL BASED COMPANY}

Data analysis on this research shows that there is no significant financial performance of local based company in Surabaya caused by direct local government election measured by current ratio, working capital turnover ratio, debt to asset and return to asset ratio. This result is contrary with the Leblang and Mukherjee (2005) that company's financial performance in United States and Britain is influenced by monetary and fiscal policy adopted by the winning party through redistribution and welfare programs after elections.

The effect which is mentioned by Leblang and Mukherjee (2005) did not happen on local scope. It may work on national scope, especially on long term performance, but not in local scope, especially in Surabaya case. There is no significant difference financial performance on three years 
period compared. It is argued that the politic effect can not influence company's financial performance on short term period. There was no such new local figure politic effect on the financial performance. The new figure of mayor can not give positive effect directly translated into local company's performance due to the limited time to implement her new policy. It is also different with Beaulieu et. al. (2006) that the uncertainty risk exposed by the political risk is more important on domestic companies. The uncertainty itself was not happen on Surabaya case because there was no difference on financial performance reflected on company's performance.

It looked like the new elected mayor need more time to implement her new policy to boost the economic or financial effect to the local company. The transition period between mayor replacement was the adaptation period before the new elected mayor implemented her new policy so that the local company can earn benefit or anticipated the unfavorable effect from the economic condition provided by the policy given by the new elected mayor. Local companies in Surabaya may earn benefit from the better supported policy on the long run period.

\section{THE EFFECT OF DIRECT ELECTION FOR LOCAL GOVERNMENT EXECUTIVE TO} MARKET PERFORMANCE OF LOCAL BASED COMPANY

Data analysis shows that there is significant difference of company's abnormal return before, as at, and after the direct election for local government executive. It means that even though the direct election for local government executive did not give any significant difference on company's financial performance, but it did to company's market performance. Market performance was more sensitive to response the local political issue, including direct election event.

This result is in line with the previous research conducted by Clara and Valkanov (2003) that the difference returns across presidential parties had larger difference in expected returns and political variables impact to stock returns is through economic policies. The mayor policy, even though had limted impact on local companies can be a signal for investor. It is reflected on the market performance. The market itself captured information and expectation from the local political issue.

Furthermore, analysis data revealed that the significant difference of abnormal return only exists on as at and after the direct election for local government executive. The abnormal return after the direct election for local government executive was significant higher than as at the election year. The abnormal return after the direct election was higher than before the direct election, even though it is not significant. This result is in line with Herbst and Slinkman (1984) that the highest return of election period was not on the election year, but after the election year, the market return was more bullish than before. This result also supported the Allvine and O'Neill (1980) that the stock price tended to rise over the election period.

It is argued that the investors were more optimistic after the election, especially if the figure who won the election was the market favorite figure. In 2010 Surabaya election case, the mayor elected was the new figure, so market expected that the new mayor with her new policy will bring a positive impact on Surabaya economy and it is expected that the company will earn benefit from the situation. That was why the company's market performance after the direct election was significantly higher than as at the election year. Before the election year the market waited the figure candidate to lead the region, so the market was more cautious due to the tight competition on the election process. Even on the election period, market still waited for the official result because there was an objection on the election result by other candidate. But, after the election was over, the market would determined whether the elected leader acceptable or not by the market's choice. Even though the market performance was different significantly, there was no difference on the financial performance. The market optimism was not justified enough by the real company's financial performance. 


\section{CONCLUSION AND RECOMMENDATION}

Several politics event should influence the company's performance. It was proved by previous research. Surabaya's direct election case on this research delivers different result, especially about financial performance. Data analysis on this research shows that there is no significant financial performance of local based company in Surabaya caused by direct local government election measured by current ratio, working capital turnover ratio, debt to asset and return to asset ratio. It is expected that the local companies can not earn benefit from the new mayor's policy on short run. The companies may earn financial benefit on the long run.

The influence of political event on market performance on this research is in line with the previous research. Data analysis shows that there is significant difference of company's abnormal return before, as at, and after the direct election for local government executive. Furthermore, analysis data revealed that the significant difference of abnormal return only exists on as at and after the direct election for local government executive. The abnormal return after the direct election for local government executive was significant higher than as at the election year. It is argued that the investors were more optimistic after the election. The market expected that company's financial performance will increase on the future. It is reflected on the better market performance booked by the company, even though there was no difference on financial performance. The market adjusted the share's price based on the expectation from the election result.

Based on this research result, the investor should be more careful to make investment decision regarding the political event, especially for the local political event. The investor can utilize to earn benefit from the better market performance, but be careful that better market performance itself was not justified by the real company's performance. The investors are recommended to keep focus on the company's performance rather than short term market optimism as the after election effect. If the investors are willing to utilize the momentum, the investors can buy the shares before the election and sell them after the election to earn short term profit. The investors should note that the good scenario will happen if only the market favorite figure won the election or at least the political event occurs safely without any turmoil.

\section{References}

Allvine, Fred, and Daniel E. O'Neill. 1980. Stock Market Returns and The Presidential Election Cycle : Implications for Market Efficiency. Financial Analyst Journal Vol. 36, No. 5 pp.49- 56.

Beaulieu, Marie-Claude, Jean-Claude Cosset and Naceur Essaddam. 2006. Political Uncertainty and Stock Market Returns: Evidence from the 1995 Quebec Referendum. The Canadian Journal of Economics Vol. 39 NO. 2 pp $621-641$.

Berman, Evan and M Shamsul Haque. 2015. Asian Leadership in Policy and Governance. United Kingdom : Emerald Group Publishing.

Clara, Pedro Santa and Rossen Valkanov. 2003. The Presidential Puzzle: Political Cycles and Stock Market. The Journal of Finance Vol. 18 No. 5 pp. $1841-1872$.

Clark, Barry. 1998. Political Economy : A Comparative Approach. USA : Paeger Publisher.

Dahl, Robert and Charles Lindblom. 2000. Politics, Economics, and Welfare. USA : Transaction Publisher.

Dixit, Avinash. K. 1996. The Making of Economic Policy : A Transaction Cost Politics Perspective. London : MIT Press.

Freeman, John, Jude C. Hays, and Helmut Stix. 2000. Democracy and Markets: The Case of Exchange Rates. American Journal of Political Science 44(3):449-68.

Gozali, I. (2011). Aplikasi Analisis Multivariat dengan Problem IBM SPSS 19. Semarang : Diponegoro University Publisher.

Hair, Joseph, William Black, Barry Babin, Rolph Anderson, Ronald Tatham. (2006). Multivariate Data Analysis. New Jersey : Pearson.

Herbst, Anthony and Craig W Slinkman. 1984. Political Economic Cycles in the US Stock Market. Financial Analysts Journal Vol. 40 No. 2 pp. $38-44$.

Huber, Jurgen and Michael Kirchler. 2013. Corporate Campaign Contributions and Abnormal Stock Return After Presidential Elections. Public Choices Vol. 156 No.1 pp.285-307.

Leblang, David and Bumba Mukherjee. 2005. Government Partisanship, Elections, and The Stock Market : Examining American and British Stock Returns. American Journal of Political Science, Vol. 49, No.4 pp. $780-802$.

Morck, Randall K. 2000. Concentrated Corporate Ownership. Chicago: University Chicago Press. 